\title{
Phytoprotection
}

\section{Research and Development Opportunities for Safe Use of Viruses}

\section{Keith A. Jones}

Volume 79, numéro 4, 1998

OECD Workshop - Sustainable Pest Management, Safe Utilization of New Organisms in Biological Control. Montréal, Québec, Canada. September 27-30, 1998.

Atelier de l'OCDE - Gestion durable des ennemis des cultures, Utilisation sécuritaire de nouveaux organismes de lutte biologique. Montréal, Québec, Canada. 27-30 Septembre 1998.

URI : https://id.erudit.org/iderudit/706159ar

DOI : https://doi.org/10.7202/706159ar

Aller au sommaire du numéro

Éditeur(s)

Société de protection des plantes du Québec (SPPQ)l

ISSN

0031-9511 (imprimé)

1710-1603 (numérique)

Découvrir la revue

Citer cet article

Jones, K. A. (1998). Research and Development Opportunities for Safe Use of Viruses. Phytoprotection, 79(4), 61-66. https://doi.org/10.7202/706159ar d'utilisation que vous pouvez consulter en ligne.

https://apropos.erudit.org/fr/usagers/politique-dutilisation/ 


\title{
Research and Development Opportunities for Safe Use of Viruses
}

\author{
Keith A. Jones \\ Natural Resources Institute, University of Greenwich, Central Avenue, Chatham \\ Maritime, Chatham, Kent ME4 4TB, UK
}

\section{INTRODUCTION}

This paper will discuss the research needs and opportunities for the safe and sustainable use of viruses. The discussion will concentrate on the use of insect pathogenic viruses, but reference will also be made to the potential use of viruses to control other pest organisms. The discussion will also focus on naturally occurring viruses, transgenic organisms being discussed elsewhere in these proceedings. However, some comment will be made on the use of transgenic organisms, in order to give a view from a Non-Governmental Organization (NGO) and developmental point of view. This being particularly relevant at a time when the introduction of transgenic organisms into agriculture is causing much debate and controversy. Similarly, although these proceedings are aimed at identifying issues and needs for research in OECD countries, reference will be made to the needs of sustainable agriculture in developing countries, where a large part of the future markets for these organisms lie.

\section{WHERE ARE WE NOW?}

An insect virus was used to control insect pests as long ago as 1913 , when an aqueous suspension of virus-infected Colias electo and Heliothis 'obtec- tus' was applied to lucerne fields (Heimpel, 1967). The potential of viruses to control other pests such as plant pathogenic microorganisms has been discussed by a number of authors, including Jeger et al. (1990). However, to date, only insect viruses, predominately baculoviruses, have reached any level of commercial-scale use, and this paper will concentrate mainly on this group.

In a recent world-wide survey, Entwistle (1998), list nearly 90 insect species that are being considered for control by viruses. The majority of viruses used are baculoviruses (nucleopolyhedrovirus, NPV and granulovirus, GV), but the list also includes the non-occluded Oryctes virus, a Parvovirus (Densovirus), Reoviruses (cypovirus), along with some other undefined viruses. From this list, commercial-scale application/introduction of viruses have been made against some 34 insect species. Studies on safety and environmental impact have been carried out on many of the viruses being used or considered for use. However, it appears that with those viruses used at a 'commercial-scale,' no safety studies have been undertaken for four of the viruses listed; no environmental impact studies for a further four viruses and neither safety nor environmental impact studies for eight of the viruses studied. This raises the issue as to whether there is a need to carry out separate safety tests for different baculovirus species or is

1 Currently seconded to CARE International, P.O. Box 1024, Colombo, Sri Lanka 
there enough evidence to say that the use of naturally occurring baculoviruses, or similar naturally occurring viruses, in pest management is safe per se?

\section{SAFETY}

There is no doubt that the safety of viruses to non-target organisms and the environment depends on the virus used. The Baculoviruses can be considered as an example of a 'safe' group of viruses. The host range of the group is restricted to arthropods and within that group almost exclusively to insects although the fact that a baculovirus has been isolated from infected shrimps does show that the host range can be wider. Also hosts are not limited to pest species; baculoviruses have been isolated from Hymenoptera (wasps), Arachnida (spiders) and Neuroptera (lacewings), as well as Diptera (flies), Coleoptera (beetles), Lepidoptera (moths and butterflies) and Crustacea. In general, individual baculovirus species have a narrow host range, infecting one or two closely related species. However, most viruses have not been extensively tested to determine host range, and therefore specificity in these cases is an assumption; although available data does indicate that this assumption is largely correct. However, some baculoviruses do have a relatively wide host range; Autographa californica multiply enveloped NPV (MNPV), the most studied baculovirus, has a host range of 39 insect species from 13 families (Cory and Entwistle, 1990). Different isolates of the same baculovirus species can also have different host ranges, for example a study of crossinfectivity of Spodoptera littoralis MNPV to other Spodoptera species found that one isolate infected only $S$. littoralis, whereas a second isolate also infected Spodoptera exempta. An isolate of Spodoptera litura NPV infected S. littoralis, S. exigua and S. exempta (Natural Resources Institute, 1993). Potency of different isolates to individual species also varies, for example Ignoffo and Couch (1981) reported a 56-fold range of activity for 34 isolates of $\mathrm{He}$ liothis NPV. It may be possible through comparison of the molecular biology of such closely related isolates to identify the genetic basis of specificity and potency. As well as providing a basis on which to select for host-range and activity, this would also open the way for studies on the stability of the genes that determine specificity and potency, and whether host range can alter following release of virus into the environment.

In the environment, there are numerous examples of natural outbreaks of baculovirus epizootics. During such outbreaks the number of infected insects, which will release virus into the environment, can run into tens of thousands or even millions per hectare. Each infected larvae can produced up to $10^{9}$ viral occlusion bodies (OB). Thus during an epizootic the amount of virus released into the environment can be as high as $10^{14}$ or more $\mathrm{OB} / \mathrm{ha}$. This can be compared to application rates for baculoviruses averaging around $10^{12}$ $\mathrm{OB} / \mathrm{ha}$. There are no records of infection or adverse effects of baculoviruses to vertebrates or non-arthropod species resulting from spray application of baculoviruses, or from the much larger innoculum resulting from natural epizootics. Moreover, there have been a number of in-depth safety studies on mammals for baculoviruses that have been developed as commercial insecticides, most notably for Heliothis NPV, which was registered in the US in 1975 as Elcar, and was granted 'an exemption from (residue) tolerance' in 1973. Naturally occurring baculoviruses thus have the advantage of being highly safe to non-target organisms. Recognising this inherent safety, some regulatory authorities have simplified registration procedures. Thus, in the US a tiered system of infectivity, pathogenicity, tetragenicity, toxicity etc. is used. If the tests are negative at one (lower) tier, there is no need to proceed to the next (more stringent) tier. There is also a push for a 'fast-track' approach, where microbial agents that are well characterized and have a record of safe field use, may require less stringent tests. A similar tiered approach has been suggested for Canada, particularly for environmental impact studies. However, 
such an approach has not yet been adopted by the European Union. There is a need to push for harmonization of approach, so that one set of information can be applicable to all OECD countries. It would be useful to undertake a comprehensive review of what safety testing has been done, and what information is publicly available. Such information would be particularly useful to developing countries, where specific regulations for registration of microbial agents are limited or non-existent. Virus formulations, particularly those produced in vivo contain microbial contaminants. Appropriate and realistic limits on the number and type of contaminants also need to be agreed and standardised. Moreover, safety testing must take into account the final formulation, containing all additives. Despite the acknowledged safety of baculoviruses, complacency in production and use should be avoided - being proteinaceous there is always the potential for allergic reaction from airborne dust or spray particles. Appropriate precautions need to be followed.

There is still a lack of information on the safety of viruses, other than baculoviruses. Data collection on the safety of the most promising viruses needs to be pushed forward, particularly host range data. With genetically modified viruses, the type of modification needs to be considered. A deletion of a gene (that does not control host range) should be regarded as less of a 'risk' than insertion of foreign genes. It is worth raising the issue here of whether genetic modification is necessary - many baculoviruses can perform effectively without modification - what are the real reasons for producing geneticallymodified viruses? Who benefits? Will the result be tying farmers to one product, and reducing access to naturally occurring organisms?

\section{ENVIRONMENTAL IMPACT}

Some discussion has occurred on the impact of baculovirus infection on parasitoids, and to a lesser extent of predators. This is particularly relevant, as it is most likely that viruses will be used as part of a comprehensive Integrated Pest Management programme. With regard to predators, there has been some concern expressed that application of virus will result in a reduced availability of prey. However, it should be realised that predators normally eat several different species, and by far the largest source of prey is the so-called 'neutral' insects that make up the majority of insects in the agro-ecosystem. Field observations confirm that the overall numbers of predators remain unaffected in virus treated fields (Figure 1).

Interactions between virus infection of the host and parasitoids are more complicated. Whilst direct infection of parasitoids by a baculovirus infecting the host has not been demonstrated, parasitoid death can occur as a result of the premature death of the host due to virus infection. However, full development of many parasitoids can occur so long as the insect does not die prematurely. Also, virus infection may result in altered physiological or nutritional conditions in which the parasitoid must develop, or may become ovipositionally unattractive. Alternatively, virus-infected individuals may be preferentially parasitized. Laboratory studies have demonstrated all of these affects, but they are not necessarily reflected the field. Jones (1990) observed the levels of parasitism of $S$. littoralis in NPVtreated and untreated lucerne fields, and reported no detrimental effect (Figure 2); however, more in-depth fieldbased studies like these are required.

These data indicate that baculoviruses are compatible with IPM programmes. However, there has generally been little research to develop appropriate IPM regimes, or to take into account the combined effects of viruses and predators/parasitoids on host population. Moreover, little research has been carried out on the recycling of innoculum through populations and later population suppression. There is a general need to undertake more detailed studies on these effects, and on the fate of virus in the environment when it is between hosts. Through study of both the ecology of the virus and 


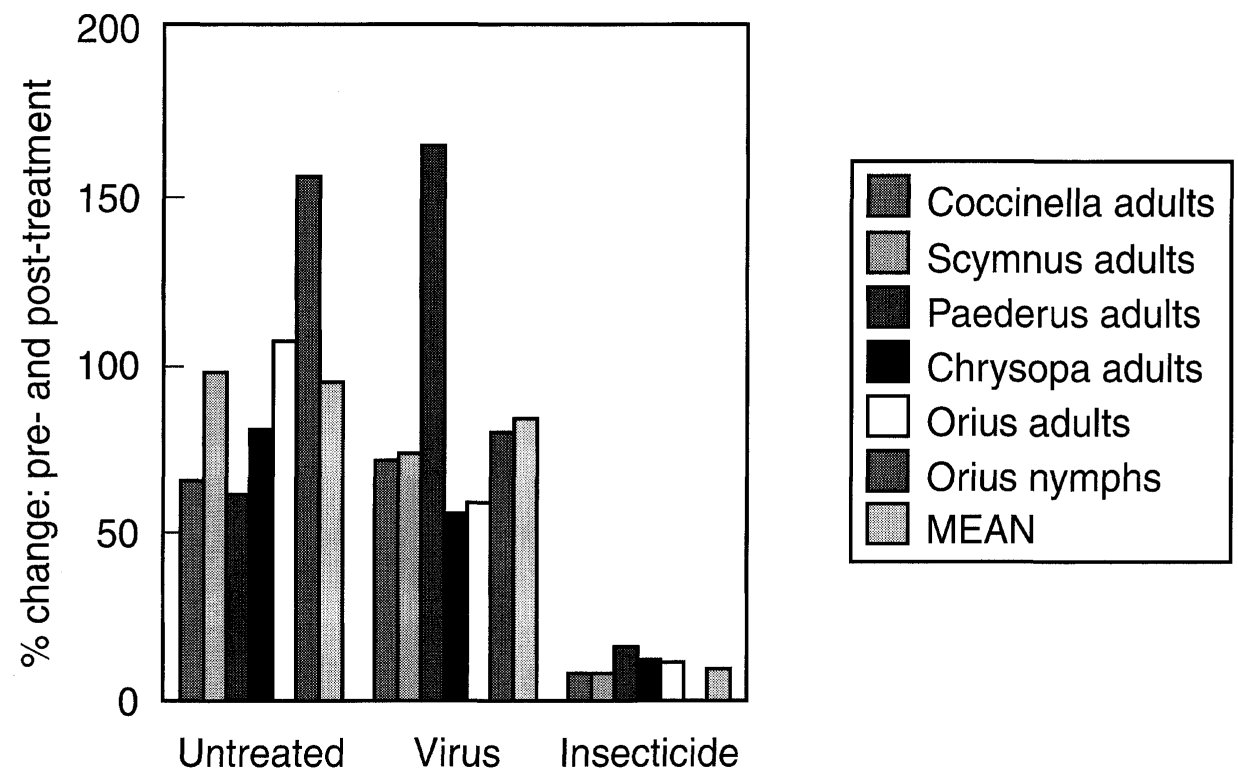

Figure 1: Population of insect predators in Egyptian cotton fields following treatment with NPV or chemical insecticides (chlopyrifos and methomyl) to control Spodoptera littoralis (data from Topper, 1984)

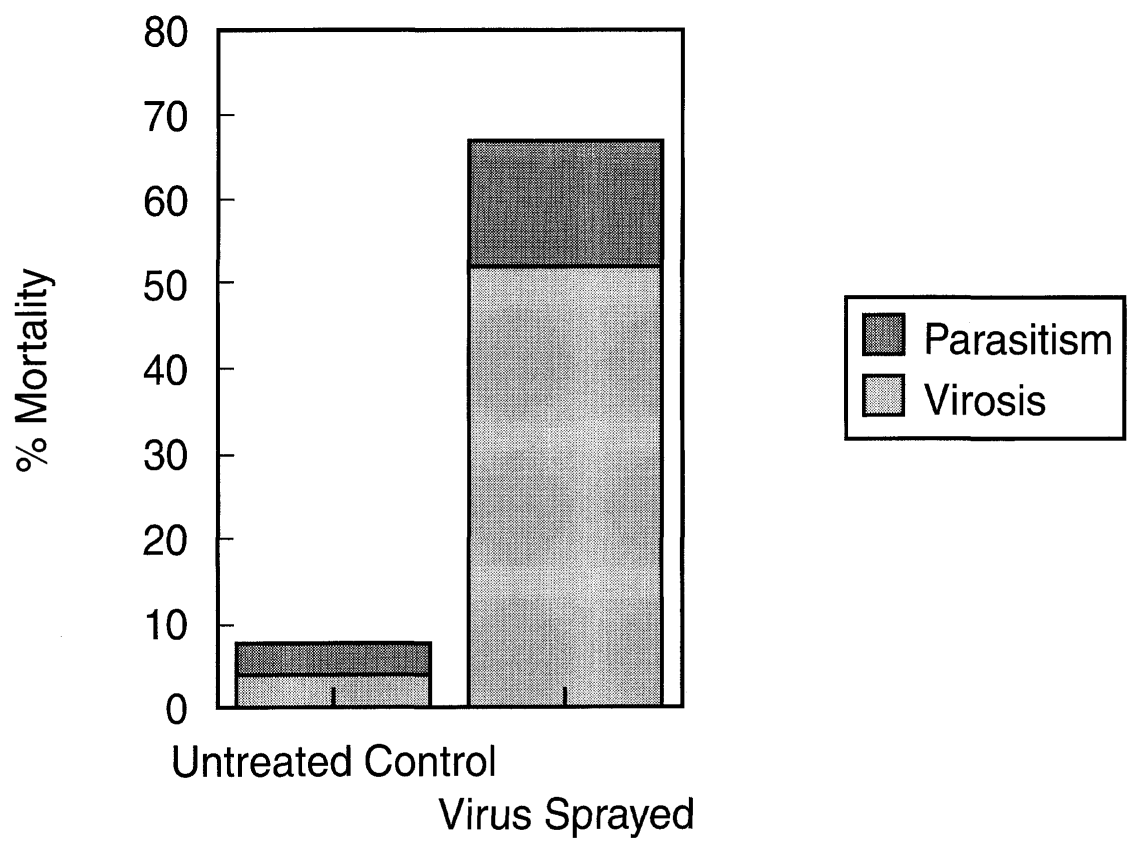

Figure 2: Mortality of Spodoptera littoralis larvae collected from lucerne fields in Crete (data from Jones, 1990). 
target insects, it will be increasingly possible to model effects and therefore predict what requirements are necessary (persistence, potency, host density etc.) for effective control. Perhaps of more relevance at present, modelling will allow prediction of the positive and negative effects of altering infectivity, speed of kill or generation to generation transmission and persistence through genetic engineering.

\section{SUSTAINABILITY}

This discussion paper deals with safety and sustainability of viruses. Sustainability of any agent will depend on a number of factors; ultimately a product must be effective and economic to be used on a sustainable basis. This means that a product must be available for use, which is stable enough to be stored for a reasonable period of time. The activity of the product needs to be predictable - this does not mean that it needs to act like a chemical pesticide. It is often said that viruses will not be adopted because they act too slowly and do not kill all of the target population. This is not always necessary, many effective products e.g. pheromones and insect growth regulators are slow acting and do not result in complete destruction of the target population. Viruses can be extremely effective when used as part of an IPM package where the narrow host range can be an advantage rather than a disadvantage. The need here is for proper education of users, so that they understand the action of the virus, and the ecology of the crop. This is the approach taken in the promotion of IPM amongst farmers in several developing countries, where through a process of Farmer Field Schools (FFS), farmers learn about the ecology of their crops and the effects of their pest management actions.

In a number of S.E. Asian countries, following FFS programmes, farmers are now recognising virus-diseased insects in their fields, collecting them, bulkingup and producing sprayable suspensions. However, this does raise the question of safety - what other microbes are also being sprayed? A methodology for quality control is required at this level, without this there is a high risk of a poor quality product being produced which will result in inadequate pest control. Even worse, a non-specific contaminant may be produced in error that might infect non-target species. This will result in a bad public perception of all viruses, whether commercially or locally produced. It is argued by some that local, low-tech production is inappropriate for microbes, as the production process is a high-tech one. However, local or low-tech production does not necessarily mean low quality production. The issue here is one of quality control - effective and reliable quality control procedures must be adopted at all stages of production, to ensure that the active ingredient - the virus, is as expected and to reduce or eliminate unwanted contaminants. There is a need to develop simplified techniques for quality control and monitoring.

One area of importance with regard to sustainability is management of resistance. Resistance development to baculoviruses has been demonstrated (e.g. Briese, 1986). There is a need to monitor this in the field, and to ensure appropriate resistance management strategies are adopted before a problem develops.

\section{CONCLUSIONS}

Insect pathogenic viruses present a good opportunity to manage a range of pest problems within an IPM framework. With the exception of insect pathogenic baculoviruses, these are at an early stage of development. Baculoviruses have demonstrated their potential as safe, effective pest control agents. Their sustainable use depends on availability, price and education of the user.

This discussion has raised a number of questions. The most important are:

1. Can insect baculoviruses, as a group, be regarded as inherently safe? Can safety data (particularly with regard vertebrate safety) from one baculov- 
irus used generically as part of the registration package other baculoviruses?

2. Is the current push towards genetically-modifying viruses necessary? Should we be concentrating our efforts on developing IPM regimes and educating farmers?

3. Is it safe to produce viruses locally at a field level? How can quality standards be maintained?

4. Are we too complacent about the possible development of resistance to viruses?

5. How safe are viruses other than baculoviruses? Should we be starting a comprehensive safety-testing program on the most promising groups?

\section{REFERENCES}

1. Briese, D.T. (1986) Insect resistance to baculoviruses. In The Biology of Baculoviruses (eds R.R. Granados and B.A. Federici), vol. II, pp. 237-264. CRC Press, Boca Raton, Florida.

2. Cory, J.S. and Entwistle, P.F. (1990) Assessing the risk of releasing genetically manipulated baculoviruses. Aspects of Applied Biology, 24, 187-194.

3. Entwistle, P.F. (1998) A world survey of virus control of insect pests. In Insect Viruses and Pest Management (eds. F.R. Hunter-Fujita, P.F. Entwistle, H.F. Evans \& N.E. Crook), pp. 188-200. Wiley, Chichester.
4. Heimpel, A.M. (1967) Progress in developing insect viruses as microbial agents. In Proceedings of the Joint US-Japan Seminar on Microbial Control of Insect Pests, 21-23 April, 1967, Fukuoka, Japan, pp. 51-61.

5. Ignoffo, C.M. and Couch, T.L. (1981) The nucleopolyhedrosis virus of Heliothis species as a microbial insecticide. In Microbial Control of Pest and Plant Diseases 1970-1980 (ed H.D. Burges), pp. 329-362, Academic Press, London.

6. Jeger, M.J., Jones, K.A. and Hall, D.R. (1990) Microbial control of pests: recent progress and prospects for developing countries. Aspects of Applied Biology, $17,425-433$.

7. Jones, K.A. (1990) Use of a nuclear polyhedrosis virus (NPV) to control Spodoptera littoralis in Crete and Egypt. In Pesticides and Alternatives (ed. J.E. Casida), pp. 131-142. Elsevier (Biomedical Division), Amsterdam.

8. Natural Resources Institute (1993) Control of insect pests with viruses. In $R e$ port on Operational Programmes: 199192. Natural Resources Institute, Chatham, UK, pp. 149-151

9. Topper, C. (1984) Report on the research and development of nuclear polyhedrosis virus of Spodoptera littoralis (Boisd.) 1979-1983 vol. 1. Overseas Development Administration and the Egyptian Academy of Science. Department for International Development, London. 